\title{
The Role of Leboku New Yam Festival in Hotel and Tourism Development in Ugep Urban of Yakurr Local Government Area, Cross River State, Nigeria.
}

\author{
Iyam, Mary Arikpo; Inah, Grace Michael; Udonwa, Rose Ekaete; Ofem, Obono \\ Michael E; Etim, JohnJohn; Eko, Eko Omini. \\ Department of Vocational and Special EducationUniversity of Calabar, Calabar, Nigeria. \\ Department of Hospitality/ Tourism, Cross River State University of Technology (CRUTECH), Calabar, Nigeria. \\ Department of Vocational and Special EducationUniversity of Calabar, Calabar, NNigeria \\ Department of Home Economics Federal College of Education, Obudu, Nigeria. \\ Department of Public Health, University of Calabar, Calabar, Nigeria. \\ Department of Economics, University of Calabar, Calabar, Nigeria.
}

\begin{abstract}
Leboku is the annual new yam festival celebrated in Ugep by the people in honour of the earth goddess and the ancestral spirits of the land for bountiful harvest. This study evaluates the role of Leboku new Yam Festival $(L N Y F)$ in hotel and tourism development. This annual celebration attracts tourists from all over the world every August to the land of Ugep people so as to witness their rich African culture, language and identity. The goal of this study was to raise consciousness on the strong relationship between Leboku New Yam Festival and hospitality as well as tourism development. Correct and précised data were collected using primary and secondary sources of data. 100 questionnaires were designed and administered, while 99 were retrieved and were accurately analyzed. LNYF promotes: inter - cultural co - operation, creates job opportunities, unity, and hotel/tourism development as affirmed from our results/findings. Tourists problems/expectations in patronizing hotels were discovered too which included: accessibility, affordability, comfortability, and hospitality. However, the study proved that LNYF - just like every other festival - is a tourist event and as such contributes not just to hotel/tourism development but also in a peoples/nations development.
\end{abstract}

Keywords:Leboku, Tourism, Hospitality, Focus Group Discussion.

\section{Introduction}

Leboku is the annual New Yam Festival celebrated in Ugep Urban, Nigeria in honour of the earth goddess and the ancestral spirits of the land in Ugep, one of the five settlements of Yakurr (Ubi, 1978). A celebration and thanksgiving to God for granting them a successful half year harvest of yams from the farms. It starts with 'Mblemi', young and old women in beautiful attire emerge from different farms and in groups and parade the town with their yield, followed by 'Janenboku', women festival day which features presentation of gifts to women by their friends and lovers. Other events includes; 'Ekoi', 'Ledemboku' (men's festival day), 'Etangala', etc. Festivals play a vital role in the development of tourisms as well as hospitality round the world and Ugep Urban inclusive.

\section{Goalof The Study}

To raise consciousness on the strong relationship between Leboku Festival and Hospitality as well as Tourism Development among people of Yakurr Local Government Area.

\section{Objectives Of The Study}

1. To find out the number of Hotels in Ugep Urban and Yakurr Metropolis, and assess their standard within four months.

2. To evaluate the percentage of tourists that utilizes the available Hotels in the Metropolis during Leboku Festival within three weeks.

3. To assess the distances of the available Hotels in the metropolis to the venue of events within two weeks.

4. Increase awareness on how and the need to prevent tourist problems in Hotel Industries by conducting a Focus Group Discussion with at least 70\% Hotel Operators and Staff in Ugep Urban within one week.

5. Increase awareness on the need for Dwellers Co-operation with Tourists and stakeholders through Focus Group Discussion within a week. 


\section{Study Area}

Ugep Urban (also Umor) is a town in a Local Government called Yakurr (also Yak $\square$ and Yakạa) in Cross River State, South Nigeria whose major and general language is Lokạa. The town is populated by the Yakurr people and blessed with an admirable Festival known as the Leboku New Yam Festival which is celebrated in Ugep. The estimated population of Ugep in 2006, projected from the 1991 Census, was 144, 421. It is located in the West-Central Corner of Cross River State, about 140 kilometers Northwest of Calabar and composed of five major geopolitical divisions (Ijiman, Ketabebe, Ijom, Ikpakapit, and Bikobiko). These people are largely Farmers and Commercial Traders. Yakurr lies between latitude 50401 and 60101 north of the Equator and longitude 8021 and 60101 east of the Greenwich Meridian and 120km (75miles) northwest of Calabar the capital of Cross River State, Nigeria. Ugep share northern and eastern boundaries with Assiga, Nyima, and Agoi Clans of Yakurr Local Government Area, southern boundary with Biase Local Government Area and Eastern boundary with Abi Local Government Area. Leboku is the annual New Yam Festival celebrated in Ugep, Nigeria in honour of the earth goddess and the ancestral spirit of the land in Ugep. Yakurr Local Government Area is created out of Obubra Local Government Area in 1987. Leboku means a period of celebration in Ugep Language and had been an exclusive affair of Yakurr Communities for celebration and thanks giving to God and the ancestral spirits of the land for granting them a successful half year harvest of yams from the farms. During this period, Tourists and lovers of culture converge at the acclaimed most culturally densely populated Urban in Africa to witness the annual festival. It is a celebration of harvest of Yams, the celebration of handwork, and celebration of womanhood. This festival has gained prominence and recognition from the Cross River State government as one of the programmes in its yearly tourism calendar and it is fast gathering attraction as a tourism package.
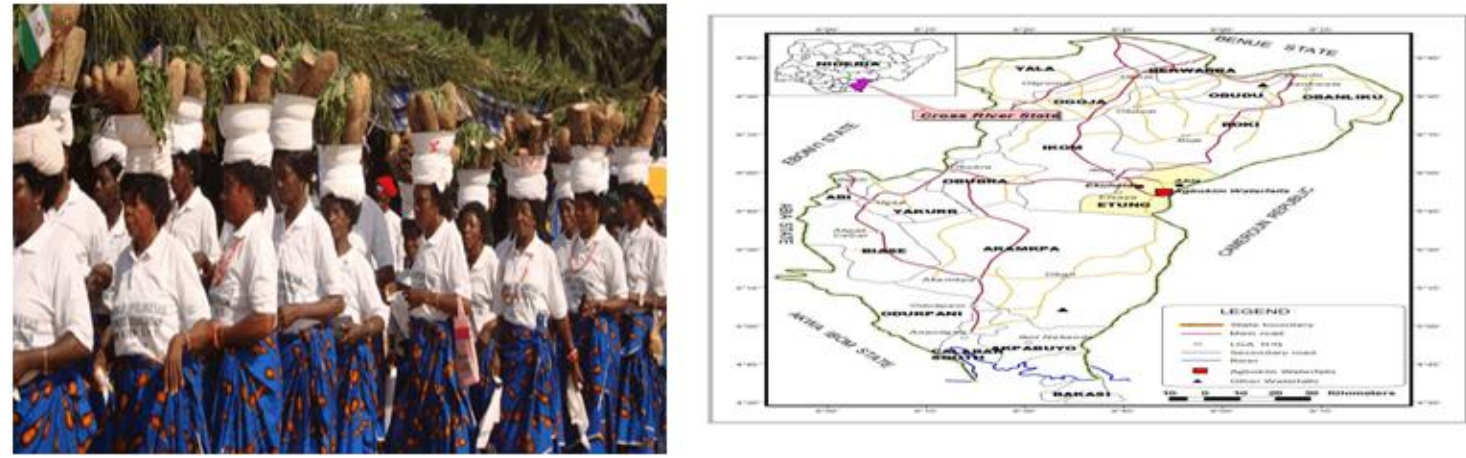

Figure 1.Showcasing of new yam byFigure 2.Map of Cross River States showingUgep Ugep women.Urban in Yakurr Local Government Area.

\section{Literature}

Festivals are unique ceremonies that displays the characteristics of ethnic groups, communities, and tribes and these features differentiates one culture or people from the other though with some little similarities across the world. Through festivals, a people's heritage, believe, way of life and language are displayed as well as their mode of communication to her supreme being. The diversities of these festivals across regions have made them tourist sites and Leboku New Yam festival is not an exemption. These cultural differences have attracted people from various parts of the world. "Europe is scheduled to be the top receiving region with 717 million tourists, followed by Eastern Asia and the pacific with 397 million, the Middle East and Southern Asia and majority of these visits is predicted to be for cultural purposes"(Bruner, 2004). New yam festivals just like every other festival and tourism have fundamental principles of exchange between people. "Tourism is centered on the fundamental principles of exchange between peoples and the expression and experience of culture (Appadurai, 2002). Tourism is cultural and its practices and structures are very much an extension of the normative cultural framing from which it emerges (United Nations Conference on the Human Environment, 1972; UNESCO, 1995). There is no doubt that tourism is a global phenomenon and estimates from the World Tourism Organization (2005), anticipate that by the year 2020, international arrivals are expected to reach over 1.57 billion. This will comprise of 1.2 billion intraregional arrivals and 0.4 billion long-haul travelers (Ajake and Amalu, 2012)". Over the years, it has been discovered that tourists are impressed and emotionally moved by a work of art, festival, musical performance or by building or objects in museum " (Ajake and Amalu, 2012). As put by Ajake and Amalu (2012), festival and musical performances are among other things that tourists look out for and Leboku New Yam Festival has it in her content. As a matter of fact, tourism is valuable development tool and a vehicle for strengthening identity.

Tourism has contributed greatly to our economy and our integrity among other areas. According to Amalu and Ajake (2012), tourism, as a contributor to the global economy, has influenced the world's economy 
in various ways as follows: it employs 204 million people worldwide or one in every nine workers, $10.6 \%$ of the global workforce, it is the world's leading economic contributor, producing an incredible $10.2 \%$ of world's gross national product, it is the leading producer of tax revenues at US\$655 billion and it's the world's largest industry in terms of gross output approaching US\$304 trillion (Goodwin, 2009). They further added that tourism accounts for $10.9 \%$ of all consumers spending, $10.7 \%$ of all capital investment and has a great multiplier effect on other industries. Tourism serves as an effective medium for transfer of wealth because here income earned in places of "residence" is spent in place of visit (tourists' destinations). Tourism is the entire world industry of travel, "hotels", transportation, and all other components, including promotion that serves the needs and wants of travellers (Honey, 2008). Another important feature of tourism is that it contributes to national integration of the people who live in different regions of the country with diverse cultures and languages (Amalu and Ajake, 2012). Leboku New yam festival, just like every other tourism, has contributed positively to hotel and tourism development, little wonder Okpoko 2006; Odunsanwo 2009, has put it that tourists seek to maximize 'consumer surplus', that is get the best experience possible for the list cost, while businesses seek to maximize (short-term) profit and host communities are interested in long-term income and employment as well as benefits.

It has been discovered that in America, Tourism served as an important source of tax revenue for local jurisdiction and this led to higher quality public services and lower local tax rates (Brown, 2009). Studies by scholars such as Rilley and Love (2000), Aniah et al, (2009) etc, have shown that tourism can be an important source of jobs creation and also offers business opportunities to local residents, but it can serve as firms to yield returns to start business locally. Tourism was also said to support local culture in rural areas by encouraging restoration to local and regional historic site and a relatively clean industry that fostered local conservation efforts (Ajake and Amalu, 2012). Following the 2002 Johannesburg summit which identified the need to explore the relationships between cultural diversity, inter-cultural dialogue and sustainable development, Robinson and Richard (2006), report it that the structures and the practices of tourism are seldom isolated from other aspects of life; rather tourism in structural term and as a set of social practices is interconnected with all aspects of daily life and that tourism touches upon peoples connections with other peoples, places and the past and in policy terms tourism cuts across the fields of planning, education, health, environment, transport, development and culture( Ajake and Amalu, 2012). Tourism as well cuts across the culture of the Yakurr people in general and Ugep urban community in particular.Thetourism industry cannot strive without the existence of auxiliary industries such as hotels, communication and commerce which provide the necessary facilities and services to ensure tourists comfort at a destination. According to Eja et al (2011), today, the establishment of hotels such as: Metropolitan (Transcope hotel), Channel View, Doris 'O', Mirage, among others in Calabar is no doubt an indicator of the growth of tourism. Calabar is regarded as one of the cities in Nigeria with a high influx of tourists due to its numerous tourism attractions and other related enterprises such as hotels, which provide auxiliary services to tourists. It is quite surprising that despite the enabling environment created by the government and the numerous tourism potentials the level of tourist influx in Calabar keeps declining. This has affected the level of patronage in the hotel industry and other existing tourism enterprises, hence leading to the rise and fall of most hotels and other tourism related outfits in the area. In this regards, it should be asked if tourism is the main catalyst for the growth of the hotel industry, what role the tourism industry plays in ensuring the sustainability of the hotel industry and the living condition of the people who solely depend on these laudable tourism potentials for sustenance (Eja et al, 2011). In the light of the above, this study was conducted addressing Leboku New Yam Festival as a tourism event as a catalyst for hotel industry and tourism development by ascertaining the level of annual patronage of tourists, major problems experienced by tourists and tourists expectations in the hotel industry.

\section{Methodology}

The research focused on The Role of Leboku New Yam Festival in Hotel and Tourism Development in Ugep Urban of Yakurr Local Government Area, Cross River State, Nigeria. In order to obtain correct and precise data without bias, primary and secondary sources of data were used. The study was limited to hotel industries in Ugep Urban. The primary data was collected using Focus Group Discussion, Key Informant Interviews and questionnaires. The secondary data was collected from journals, existing literature and published materials. Questionnaires were administered to hotel operators, managers and staff as well as dwellers of Ugep Urban through random sampling. The number of hotels in our target population was ascertained through Street Mapping. The percentage of tourists that patronizes the available hotels was ascertained through Key Informant Interviews with Hotel operators in our population of interest. A semi - structured questionnaire was administered to one hundred (100)respondents to get their perception on the topic in question but only ninety nine (99) questionnaires were retrieved and analyzed, which made up our sample population. Our Focus Group Discussion comprised of all hotel operators of the thirteen (13) hotels discovered as at the time of this study which include; Adisun Guess Inn.Hotel,Cravings Hotel Ltd.,Hilltop Lodges Hotel,IvanyHotel,Mangoman Hotel, Obitex Elegant Hotel,ScenarioHotel,Sugar Hill Guest House, Summer International Guest house, Treasure 
Resort Hotel,View Suit Hotel, White House Hotel andYakurr Local Government Guest House. Our respondents were administered the questionnaire to respond to and we collected the questionnaire as soon as the responses were completed to avoid indoctrination by other persons.

Data collected was analyzed and presented using descriptive and quantitative techniques. The descriptive technique includes the use of graphs, tables, charts, mean, standard deviation and simple percentages.

\section{Findings/Results}

This study highlighted the role Leboku New Yam Festival plays in the development of tourism and hospitality as well as raising awareness on the need to promoting tourism and hospitality as it affects our holistic health.

Table 1\&2.Shows the raw data obtained from the field survey and the presentation of the tools used for data collection, explicitly showing the frequencies, means, standard Deviation, and the percentages as analyzed.

Table 1.Primary data showing tools used in the field/results in Mean and Standard Deviation.

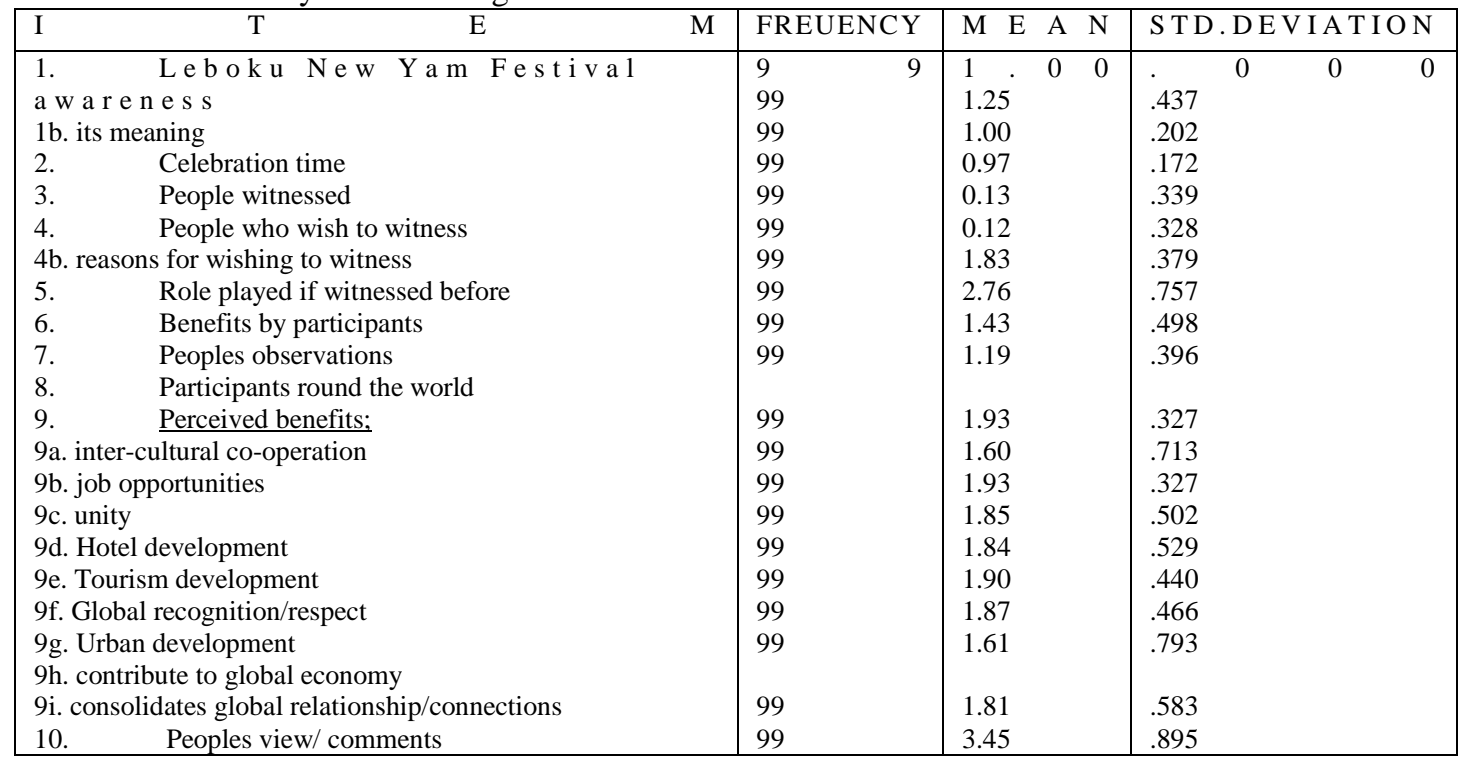

The first tool in table 2 shows the elimination method used in this study which emphasis was on knowing whether or not our respondents have any idea about Leboku New Yam Festival celebration and this shows that one hundred percent $(100 \%)$ had fool knowledge of the topic in question. From this, many meaning/definitions of Leboku New Yam Festival arose: $74.7 \%$ defined it as celebration of new yams while $25.3 \%$ gave other definitions that still hits on celebration of the Yakurr people in worship of the goddess of harvest whose period of celebration is affirmed to be every August of each year.

Table 2.Detailed raw data showing results in simple percentages

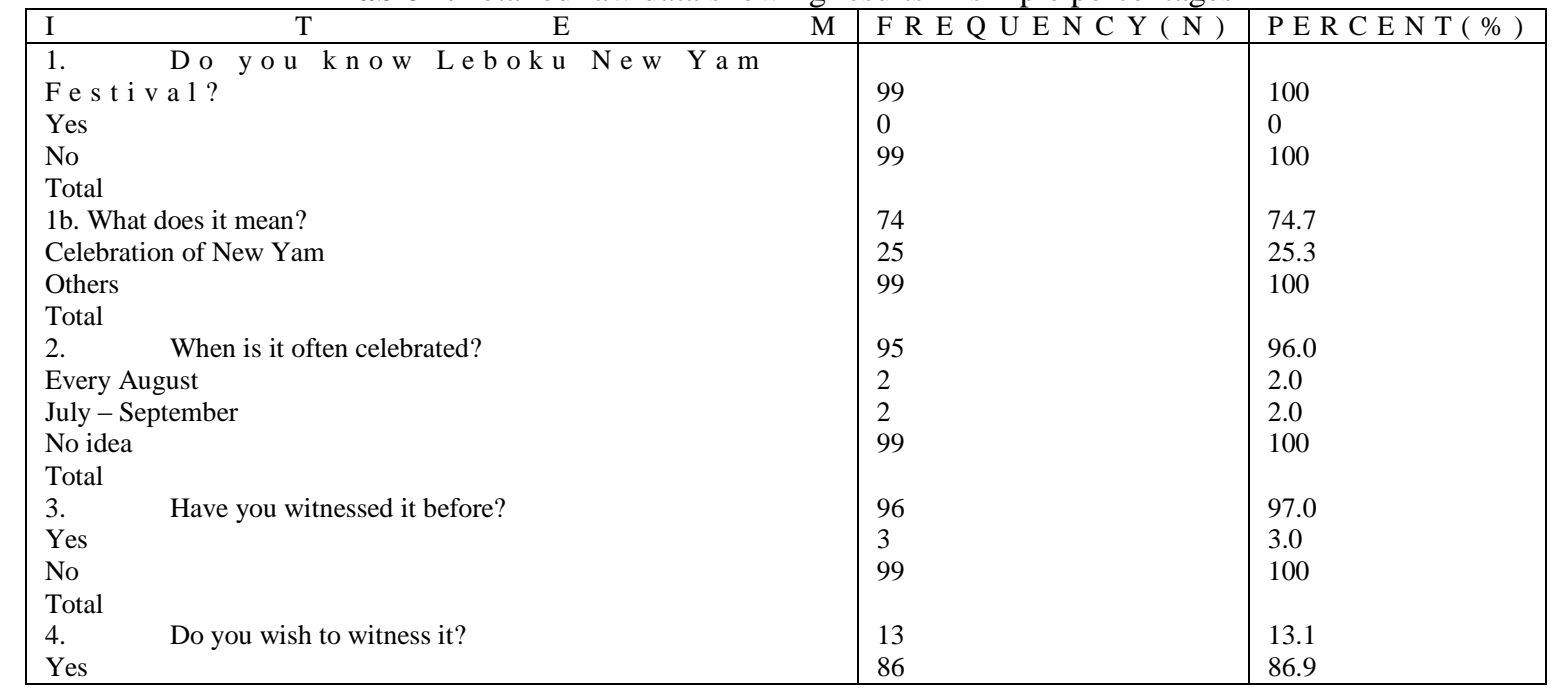




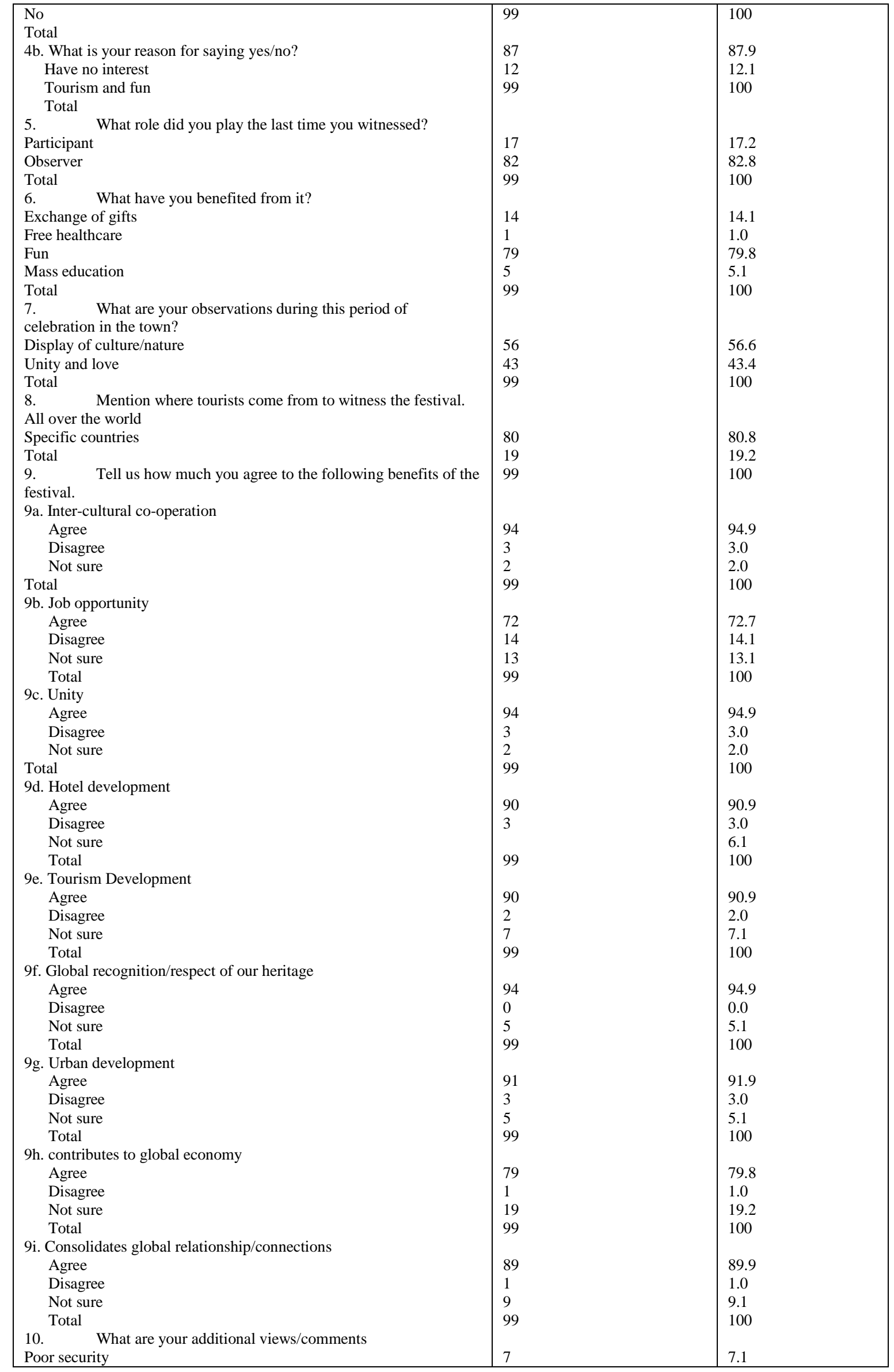


The Role of Leboku New Yam Festival in Hotel and Tourism Development in Ugep Urban of Yakurr ....

\begin{tabular}{|l|l|l|}
\hline Marginalization & 6 & 6.1 \\
Injustice & 21 & 21.2 \\
Satisfactorily & 65 & 65.7 \\
Total & 99 & 100 \\
\hline
\end{tabular}

Still from the analysis as shown in table $-2,97 \%$ of our respondents have witnessed it as observers and participants, reviling that this celebration showcases the peoples kind gesture as it involves exchange of gifts, free healthcare, fun, mass education of the people on health issues, display of culture, showing of love and people come from far and near all over the world to witness/observe the festival.

The analysis show how our respondents strongly believe in the perceived benefits of Laboku New Yam Festival in terms of enhancing inter - cultural co - operation with people from other parts of the world, job opportunity creation, unity, hotel development, tourism development, increase in global recognition/respect of the heritage of Ugep people, development of Ugep urban, contributing to global economy and consolidating global relationships/connections of the people to the outside world, that is; $94.9 \%, 72.7 \%, 94.9 \%, 90.9 \%$, $90.9 \%, 94.9 \%, 91.9 \%, 79.8 \%$, and $89.9 \%$ respectively. More details are represented in figure $3 \& 4$ bellow.
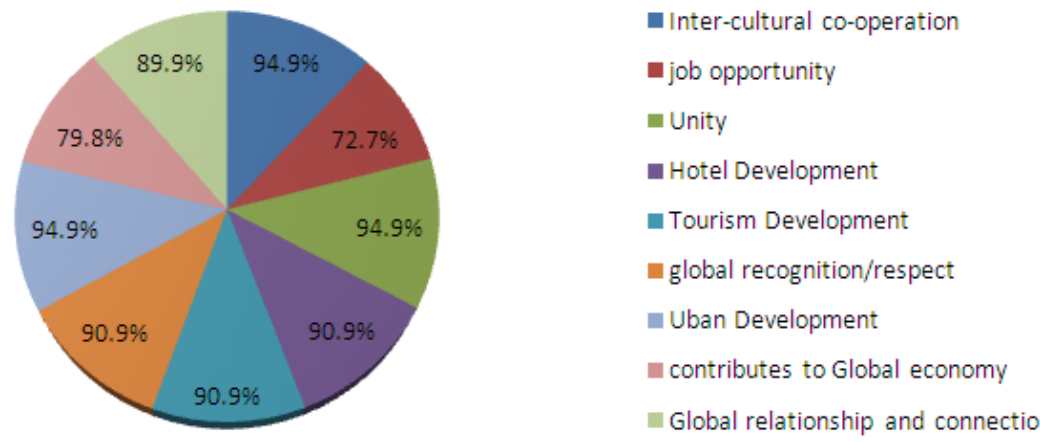

Figure 3. Benefits of Laboku New Yam Festival. Source: Field Survey, 2013.

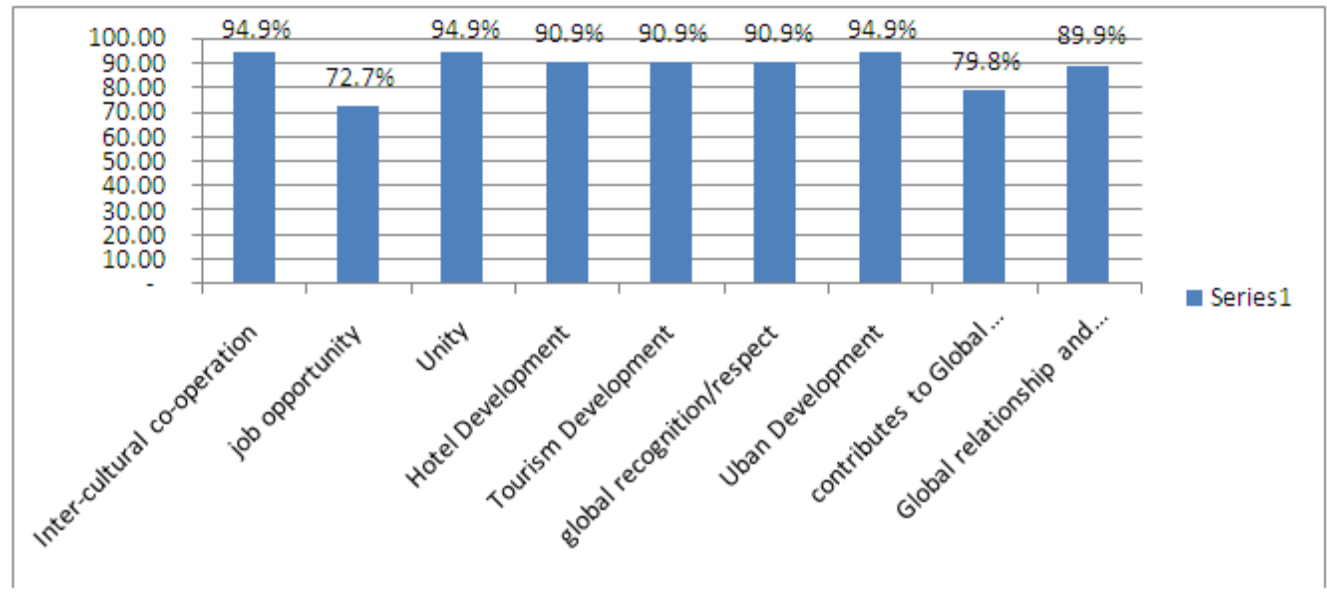

Figure 4.Benefits of Laboku New Yam Festival. Source: Field Survey, 2013.

More precisely from our findings, 90.9\% agreed to the fact that Laboku New Yam Festival (LNYF) plays a vital role in hotel/tourism development, while 3.0\% disagreed to hotel development, $2.0 \%$ disagreed to tourism development, while $6.1 \%$ and $7.1 \%$ were not sure at all. Figure 5 illustrates further. Though some percent of our responded were uncertain whether LNYF develops hotels and tourism, however the analysis still portrays that it does. 

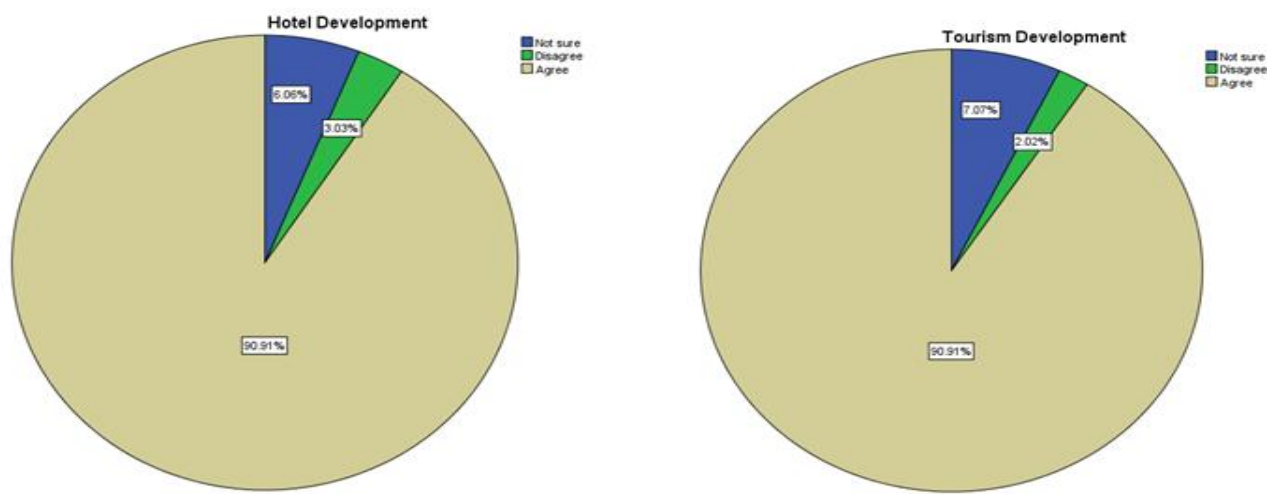

Figure 5.The role of Laboku New Yam Festival in Hotel/Tourism Development.

Source:Field Survey, 2013.

\section{Discussion}

In attempting to find out the role Laboku New Yam Festival (LNYF) plays in the development of hotels in Ugep Urban and tourism other benefits were also discovered as well as problems/expectations of tourists and hotel operators. It has been discovered that LNYF creates job opportunities, unity, enhancing global recognition and consolidates the relationships and connections our population of interest have with other parts of the world.

The results/findings from our Focus Group Discussion demonstrated the challenges of hotel operators which hit on the expectation of tourists and as such are tourists' problems which are seldom considered before the utilization of any facility in the hotel industry. These tourists problems includes; accessibility, affordability, comfortability, and hospitality. Each of these challenges accounts for a giving percent of barrier between hotel operators and lovers of tourism, accessibility accounting for $16.67 \%$, affordability 16.67 , comfortability $33.33 \%$, and hospitality $33.33 \%$ too respectively and this is vividly shown in figure 6(a). The goal of the study was evaluated and was achieved after the study as objective number one was achieved by ascertaining the number of hotels in Ugep Urban as listed in the methodology of this paper and we found out that over $70 \%$ of tourists utilize the available hotel facilities in our priority group. However, the distances of these hotels to the venue of event, among other factors, have been the determining factors tourists consider for utilization of these hotels as shown in figure 6 and of such, hotels that are closer to the venue of events are more patronized. On this note, there was an increase in awareness on how to prevent these tourists' problems and the need for it as well as the need for Dwellers Co - operation with tourists and stakeholders through our Focus Group Discussion which has helped us to achieve our set objectives of the study. From our results/finding, we have discovered that, festivals do not only develop tourism and the hotel industries but also develops the people and the nation.
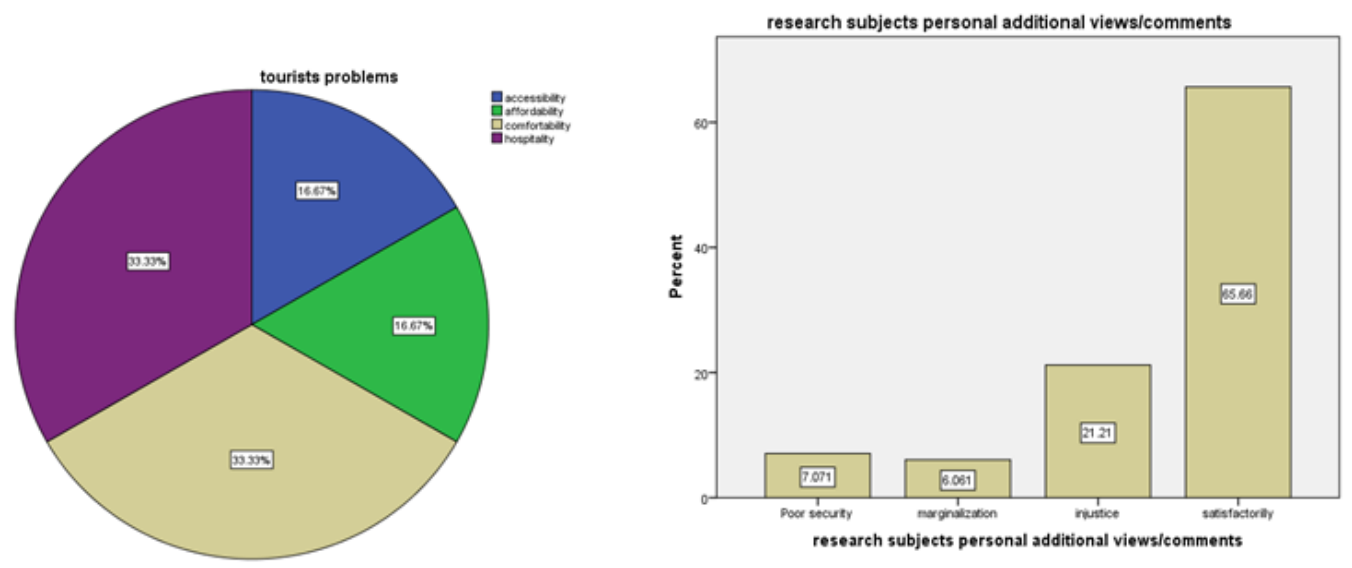

Figure 6(a): Tourists Problems.Figure 6(b): views of research participants on LNYF.

Source; field survey, 2013

More so, from the analysis, $65.66 \%$ of our research participants as shown in figure 6(b) disclosed it that they as satisfy with how Laboku New Yam Festival (LNYF) is often organized and celebrated. However, there were other challenges discovered in the course of this study which included: poor security during the period of celebration, marginalization in not giving room for the physically challenged to partake in the contest of Mr. 
/Mrs. Leboku, and injustice in awarding prizes to winners including the best harvester. Figure 6(a) clearly puts it that $7.071 \%$ of our respondents were hitting on poor security, $6.061 \%$ on marginalization, while $21.21 \%$ on injustice.

\section{Conclusion}

Laboku New Yam Festival - just like other festivals - is a tourist event that showcases culture, religion, language, and nature and as such serves as a positive catalyst in the development of hospitality and tourism.It attracts people from all over the world down to Ugep Urban in Yakurr Local Government Area of Cross River State, Nigeria. It showcases the culture of Africa in an Ugep mans' way, revealing the strength of an African man in the production of farm produce which is a sign of the ability to feed her people and as such, one of the proves for wealth. It is an annually event which gives room for a Yakurr man and woman to showcase his harvest of new yams in order the thank god for bountiful harvest which affirms with the belief that appreciation for one good would let loose of more good to come.

\section{Recommendation}

The scope of this study spanned from Leboku New Yam Festival, hotels/operators, tourists/tourism as well as the dwellers of our community of interest and stakeholders which suggests that all these areas need a redress and based on these, we therefore recommend the following:

1. Education of dwellers on the need to co - operate with tourists in order to make them feel safe and with the organizers to make the festival a success.

2. The need for organizers to be fair in their judgments by ensuring justice as this will consolidate the participation of people and as well set a good pace for tourism to strive.

3. The need for hotel operators to improve on their level of hospitality through regular updating on their customer care/services, control of charges to address the issue of affordability and updating on the comfortability of their industries by making the environment conducive enough for clients.

4. The is need for the support of government both local and state to the organizers as well as the community of event through provision of motor - able roads, constant power, adequate/safe water supply and reliable security to reduce tourists problems and hotel operators challenges as these will address the issue of security, accessibility and comfortability.

This study really demonstrates that there is a strong relationship between festivals, tourism and hospitality development.

\section{References}

[1]. Ajake, A. O. \&Amalu, T. E. (2012): The Relevance of Tourism on the Economic Development of Cross River State, Nigeria. Journal of Geography and Regional Planning, Vol. 5(1), pp. 14 - 20.

[2]. Amalu, T. \&Ajake, A. (2012): An Assessment of the Employment Structure in the Tourism Industry of Obudu Mountain Resort, Cross River State, Nigeria. GeoJournal of Tourism and Geosites, Year V no.1, vol.9.

[3]. Aniah, E. J., et al (2009): Report Potentials as a Strategy for Sustainable Tourism Development in Plateau State, Nigeria. J. Sustain. Dev., 2(2): 73-79.

[4]. Appadurai, A. (2002): Cultural diversity; A Conceptual Platform. In.K.Stenou (ed.) UNESCO Universal Declaration on Cultural Diversity.UNESCO Publishing, Paris, pp.9-16.

[5]. Brown, D. M. (2009): Rural Tourism; An Annotation Bibliography. Economic Research Service, US Dept. of Agricultur, Washington, D. C.runer, E. M. (2004): Culture on Tour; Ethnographies of Travel. The University of Chicago Press, Chicago, p.39.

[6]. Eja, E. I., et al (2011): Tourism as a catalyst for hospitality Industry Development in Calabar, Nigeria. e-Review of Tourism Research (eRTR), Vol. 9, No. 1.

[7]. Goodwin, H. (2009): Tourism, Local Economic Development and Poverty Reduction, Applied Research in Economic development, 5(3), 55-64.

[8]. Honey, M. (2008): Ecotourism and Sustainable Development;Who Owns Paradise?, Washington DC; Island Press.

[9]. Odunsanwo, A. (2009): Tourism Education; passport to sustainable Tourism Development in Nigeria, Port-Harcourt; Garden Bar Publishers.

[10]. Okpoko, P. U. (2006):Issues in Tourism Planning and Development, Nsukka; Afro-Orbis Publishers.

[11]. Riley, R. W. \& Love, L. (2000): The State of Qualitative Tourism Research. Ann. Tourism Res., 1(17); 164-187.

[12]. Robinson, M. \&Richard, D. (2006): Tourism, Culture and Sustainable Development. Nimes Publishers, Paris, p. 1-29.

[13]. Ubi, O. A. (1978): The Yakurr; A Reconstruction of Pre-colonial History, University of Lagos PhD Thesis.

[14]. United Nations Conference on the Human Environment, (1972): Declaration of the United Nations Conference on the Human environment, Stockholm, UN Publication, New York and Geneva.

[15]. UNESCO, (1995): The Cultural Dimension of Development towards a Practical Approach. UNESCO Publishing, Paris, p.2024.World Tourism Organization. (2005): Year Book of tourism Ed. WTO, Madrid. 